\title{
Minireview
}

\section{Use of nucleic acids amplification methods in Marek's disease diagnosis and pathogenesis studies}

\author{
Vladimír Zelník \\ Institute of Virology, Biomedical Research Center, Slovak Academy of Sciences, Dúbravská cesta 9, \\ 84505 Bratislava, Slovak Republic
}

Received February 2, 2020; accepted March 3, 2020

\begin{abstract}
Summary. - Marek's disease (MD) is a lymphoproliferative disease of chickens with strong economic impact on poultry industry. Although successful vaccination has enabled control of the disease, outbreaks occur in commercial flocks, resulting in substantial economic losses. Together with vaccination, accurate and fast diagnosis of MD remain the most important tools for its efficient control. MD diagnosis currently relies mainly on the identification of its causative agent, Marek's disease virus type 1(MDV-1). Nucleic acid amplification techniques have been successfully applied for identification of MDV DNA in field samples and also for studies of virus-host interactions. In this review we want to summarize recent advances in the development of standard and quantitative PCR techniques and their use in rapid MD diagnosis, including differentiation of pathogenic and vaccine MD viruses. PCR protocols have served as a useful tool for clarification of processes associated with MDV infection in chickens, such as virus spread and release, and effect of vaccine virus on progress of MD. Here, we also describe a novel multi-species qPCR methodology for identification and quantification of MDV DNA, enabling its detection in various bird species that are the most susceptible to MDV infection.
\end{abstract}

Keywords: Marek's disease; MDV; diagnosis; nucleic acid detection; duplex quantitative PCR

\section{Overview of methods for Marek's disease diagnosis}

Primary diagnosis of MD in the field is based on clinical signs and examination of gross or microscopic lesions in tissues of infected birds. MD infection is then usually confirmed by virological or immunological methods in the laboratory to confirm the presence of the causative

E-mail: viruzelo@savba.sk; phone: +421-2-59302-463.

Abbreviations: $\mathrm{CEF}=$ chicken embryo fibroblasts; $\mathrm{CKC}=$ chicken kidney cells; $\mathrm{DEF}=$ duck embryo fibroblasts; $\mathrm{HVT}$ = herpesvirus of Turkey; LAMP = loop-mediated amplification; $\mathrm{LL}=$ lymphoid leukosis; $\mathrm{MD}$ = Marek's disease; $\mathrm{MDV}$ = Marek's disease virus; $\mathrm{vV}^{+}=$very virulent plus (MDV-1 strains) agent, Marek's disease virus (MDV-1). Classical MD diagnostic methods include identification of MDV-specific antigens or antibodies and viral nucleic acid detection. Although modern methods enable direct viral antigen or nucleic acid (NA) identification in clinical samples, virus re-isolation is required for further detailed analyses of an MDV isolate. As MDV and its serologically related vaccine viruses frequently occur in poultry flocks, virological diagnosis alone does not necessarily explain the cause of the tumors in the field. Nevertheless, pathological observations of the disease together with the positive identification of MDV usually confirm the presence of MD in a flock.

MDV-1 belongs to the subfamily Alphaherpesvirinae, classified with its serologically related viruses, Marek's disease virus serotype 2 (MDV-2) and herpesvirus of 
turkeys (HVT) within the genus Mardivirus (King et al., 2012). Viruses of all three MDV serotypes serve as live vaccines against $M D$; there are used attenuated strains of MDV-1 (Churchill et al., 1969a; Rispens et al., 1972b) as well as strains of non-oncogenic MDV-2 (Schat and Calnek, 1978) and HVT (Okazaki et al., 1970; Witter et al., 1970). Vaccine viruses do not prevent super-infection of birds with pathogenic MDV-1; successful vaccination usually leads to the prevention of occurrence of pathological changes (Morimura et al. 1998; Baaten et al., 2004). Consequently, MDV-1 persists in the birds throughout their lives and can spread horizontally in flocks by virus particles released from feather epithelium to dust and dander, where they are relatively resistant to environmental conditions (Calnek et al., 1970, 2001). Intensive poultry production and forceful use of vaccines can most likely be accounted for increased virulence of MDV-1 isolates (Davison and Nair, 2005). Use of serologically related herpesviruses as live vaccines against MD has represented additional challenge for the development of specific laboratory methods for pathogenic MDV-1 identification and differentiation from non-pathogenic vaccine viruses.

Classical methods of MD diagnosis are particularly complicated as it is a complex disease with varying clinical signs and pathology that can be attributed to the presence of different MDV-1 strains in field and is also dependent on the genetic background of the host. In addition, it can be confused with avian lymphoid leukosis (LL) caused by retroviruses. Although the etiological differentiation between MD and LL was elucidated in the sixties of the last century (Biggs, 1961, 1976), confusions still have occurred as both infectious agents cause lymphoid cell tumors that are often difficult to differentiate just based on gross pathological examination. Recently described sporadic paralysis associated with polyneuropathy in chickens could be also misinterpreted as MD (Matiasek et al., 2008; Gall et al., 2018).

Currently, the MD symptoms are classified as "classical" neural form of fowl paralysis, acute leukosis with lymphomatous tumors in visceral organs (Payne et al., 1976) and more recently characterized acute transient paralysis (Witter et al., 1999). All these pathological changes are associated with infiltration of proliferating lymphoid cells in organs such as peripheral nerves, liver, kidney, spleen, gonads, heart, proventriculus, skeletal muscle and skin (Addinger and Calnek, 1973). However, other clinical signs might be also observed, such as early mortality caused by severe cytolytic infection of lymphoid tissues with newly isolated vv+ MDV-1 strains (Calnek,2001; Witter et al. 2005).

Laboratory diagnosis of MD focusses mostly on isolation of MDV-1 and identification and characterization of its virions, its DNA or antigens, as well as on detection of MDV-specific antibodies.
In vitro isolation and propagation of the MD causative agent is a prerequisite for further characterization of the MDV-1 isolate. However, it is time consuming and good experimental skills are required for successful adaptation of a field virus for in vitro propagation. Although chicken embryo fibroblasts (CEF) are common substrate for MD vaccines production, they are not suitable for primary MDV-1 re-isolation, and alternative use of chicken kidney cells (CKC) or duck embryo fibroblasts (DEF) is more favorable for in vitro propagation of MDV-1 isolates (Churchill and Biggs, 1967; Nazerian et al., 1968; Solomon et al., 1968; Schat, 2005). Virus adaptation for in vitro cell culture is performed by co-cultivation of inoculum (whole blood, white blood cells, splenocytes or suspension of tumor cells) with culture of DEF or CKC. For re-isolation of MDV-2, HVT or attenuated strains of MDV-1 from biological samples, CEF can be also used as substrate. In general, virulent field MDV-1 viruses propagate slower in cell culture; cytopathic effect (CPE) appearing 5-8 days postinoculation is characteristic by small to medium plaques of rounded refractive cells or syncytia. Continuous passage of the virus in cell culture leads to its adaptation and faster replication in vitro; however, it is also associated with attenuation of the oncogenic potential of the virus (Churchill et al., 1969; Nazerian, 1970) and structural and gene expression changes in MDV-1 genome (Churchill et al., 1969; Fukuchi et al., 1985; Maotani et al., 1986; Ross et al., 1993). Indeed, these genetic changes served as the first genetic markers for differential diagnosis between virulent and attenuated MDV-1 strains.

Immunological methods for identification of MDV-1 antigens or detection of MDV-specific antibodies in sera of infected birds have been used widely after successful isolation and characterization of MD causative agent in the late sixties of the last century. A conventional method, still often in use, is agar gel precipitin (AGP) assay, where the serum is reacted with MDV antigen (Chubb and Churchill, 1969). Presence of either MDV-1 antigens or MDV-1 positive sera can be tested in the assay. As the source of the antigen can serve crude lysate of in vitro infected cells or skin extract or feather pulps (Haider et al.,1970; Adldinger and Calnek, 1973). In general, feather follicles of infected birds serve as a good, easily accessible source of MDV-1 antigens and viral DNA (Calnek et al., 1970; Haider et al., 1970; Davidson et al., 1986); tips of feathers from affected birds can be stored in cold, dry place for several weeks for further antigen and DNA analyses.

Direct or indirect immuno-staining assays are other methods for detection of MDV-specific antigens in samples. The test is more sensitive and specific when monospecific sera and, better, monoclonal antibodies are available. Preparation and use of monoclonal antibodies enabled detailed analyses of MDV-1 and HVT antigens, 
and detection and differentiation of the viruses (Ikuta et al., 1982; Lee et al., 1983a). Monoclonal antibodies or monospecific sera can be used in various immunological techniques, however, for diagnostic purposes immunofluorescence (Ikuta et al., 1982; Lee et al., 1983a) or immunoperoxidase staining (Silva et al., 1997) of in vitro propagated virus isolate seem to be the most straightforward applications.

Widespread use of the enzyme-linked immunosorbent assay (ELISA) for diagnostic detection of MDV-specific antibodies was hampered by high background readings, as homologous cellular antigens interfere with the assay and by the nature of MDV as an immnunosuppressive agent depleting antibody-producing $B$ cells and thus naturally reducing titters of specific antibodies. ELISA test utilizing homologous cell system was reported by Cheng et al.(1984). Use of alternative heterologous system for production of MDV antigen based on CKC reduced the background and it was found that reliable ELISA readings can be observed in sera from birds that were infected with MDV-1 and were protected against MD compared to sera from birds that received vaccine virus only or were not protected against MD (Zelnik et al., 2004).

\section{PCR-based methods for MDV DNA detection}

Introduction of the polymerase chain reaction (PCR) in the eighties of the last century has revolutionized rapid detection of many infectious agents including MDV-1. As the complete DNA sequences of MDV-1, MDV-2 and HVT genomes are available (Tulman et al., 2000; Afonso et al., 2001; Izumiya et al., 2001; Kingham et al., 2001), manual or software-assisted design of specific PCR primers is not problematic and depends on actual requirements and purposes. Use of quantitative PCR technique is becoming more popular, however, its common use is hampered by requirements for special and expensive equipment and consumables.

As MDV-1 is ubiquitous, use of vaccines is widespread and detection methods are becoming more sensitive, differentiation between virulent and vaccine viruses has appeared to be more and more important. Use of MD vaccines based on serotype 1 viruses such as CVI 988 (Rispens et al., 1972a) further underlined this requirement. Some of possible ways of virus differentiation were outlined in previous text, however, many of them, such as virus plaque morphology or immunological staining, are not specific enough and include cell culture adaptation of the virus that is time consuming and requires relevant experience. These obstacles in virus detection and differentiation appeared to be easily solved by introduction of the first PCR tests in MDV diagnostics.
Data on genetic variability between MDV-1 isolates provided rather complex information (Spatz et al., 2012). Nevertheless, visible changes between virulent MDV-1 viruses and their attenuated counterparts were described earlier in the BamHI-H fragment of the MDV-1 genome as an expansion of the region (Fukuchi et al.,1985; Maotani et al., 1986). This expansion is due to multiplication of $132 \mathrm{bp}$ repeats that are present in virulent strains in 2 or 3 copies but in highly passaged viruses their number is variable and can reach several tens (Ross et al., 1983). This fact enabled development of a simple PCR test to differentiate between virulent and passaged MDV-1 viruses (Silva, 1992; Becker et al., 1993; Kopáček et al., 1993). For the time being, PCR analysis of the expansion of $132 \mathrm{bp}$ repeats during multiple in vitro passage seems to be a reliable differentiation method suitable also for attenuated CVI988/ Rispens vaccine strains. Variability in the MDV-1-specific meq gene was also reported, but this polymorphism cannot be utilized for vaccine and virulent MDV-1 strains differentiation (Chang et al., 2002). Another CVI 988/ Rispens-specific insertion represented by single $116 \mathrm{bp}$ repeat was found upstream of the MDV-1 long ICP4 ORF (Majerčiak et al., 2001) and can be easily detected by PCR; however, with the recent data available (Spatz et al., 2012), this method cannot be applied for differentiation of all CVI988/Rispens virus variants. PCR methods specific for MDV-1 can definitely distinguish virulent MDV-1 infection from retroviruses-induced leucosis (Davidson et al., 1995) or peripheral neuropathy (Gall et al., 2018).

Real-time PCR methodology allowed absolute quantification of MDV-1 in biological samples (Baigent et al., 2005b; Walkden-Brown et al., 2013) and has proven to be a valuable method not only for MD diagnostics but also for clarification of processes related to MDV infection, focusing on virulent MDV load and spread (Baigent et al., 2005a, 2007; Haq et al., 2012).

Real-time PCR differentiation between virulent MDV-1 isolates and CVI988 vaccine strain was described by Zelnik et al. (2008) and further improved and validated by Baigent et al. (2016). The method is based on H19 epitope point mutation in pp38 gene (Cui et al., 1999) and could be applied to monitor kinetics of replication of commercial CVI988 vaccine and virulent MDV in feather tips and blood of vaccinated and challenged experimental chickens.

We used real-time PCR technique to study the effect of hypoxia on MDV-transformed cell lines by analysis of viral genome replication and expression of transformation- and reactivation-related viral genes by novel duplex quantitative PCR method. As two cell lines carrying latent MDV genome were used in the study, the chicken lymphoblastoid cell line CU41 and the quail fibrosarcoma cell line QT35, we introduced novel qPCR methodology 
Table 1. Primers and probes for multispecies quantitative multiplex MDV PCR

\begin{tabular}{ll}
\hline Primer $/$ probe & Sequence $\mathbf{( 5}^{\prime}-\mathbf{3}^{\prime} \mathbf{)}$ \\
\hline chqB-Act_Pr1 & GAC GGA CTA CCT CAT GAA GAT CCT \\
chqB-Act_Pr2 & TGA TGT CAC GCA CAA TTT CTC TCT \\
chqB-Act_Probe & JOE- CAG AGA GAG GCT ACA GCT TCA CCA CCA CA-BHQ1 \\
MI4-Pr1 & GAT GGC GAT CTG GAA ACA TGT \\
MI4-Pr2 & CCC CTC CCC GGA ATC C \\
MI4-Probe & FAM- CGA CGT TCC GGT GAG TAG TAT TGG ATG G -TAMRA \\
MEQ-Pr1 & GAG CCG GAG AGG CTT TATG C \\
MEQ-Pr2 & ATC TGG CCC GAA TAC AAG GA \\
MEQ-Probe & FAM-CGT CTT ACC GAG GAT CCC GAA CAG G -TAMRA \\
\hline
\end{tabular}

setup comprising primer and probe design that enables multi-species detection of house-keeping gene, the $\beta$-actin gene, in chicken, duck, quail and turkey. Thus, a single method could be applied to study MDV genome load and viral genes expression in both chicken CU41 and quail QT35 cells. MDV-specific primers and probes targeted the ICP4 transactivator gene and/or the MEQ oncogene. The primers and probes are listed in Table 1.

\section{Other nucleic acid amplification methods in MDV diagnostics}

As an alternative amplification method to detect MDV-1 DNA in feather follicles and other biological samples there was introduced isothermal loop-mediated amplification (LAMP) methodology (Woźniakowski et al., 2011; Angamuthu et al., 2012; Wei et al., 2012). These protocols provide cheaper alternative to PCR methods and claim to be more sensitive than standard PCR assays. Differentiation between viruses of three MDV serotypes is possible by LAMP methodology (Woźniakowski et al., 2013); however, there is no LAMP protocol available that could distinguish virulent MDV-1 isolates from CVI988/ Rispens vaccine strains.

Rapid real-time recombinase polymerase amplification for MDV-1 detection was introduced recently (Zeng et al.,2019) with sensitivity that is claimed to be sufficient enough for MDV-1 detection in clinical sample but does not enable any kind of differentiation between serologically related avian herpesviruses.

\section{Conclusions}

Marek's disease continues to be a serious threat for poultry production despite widespread vaccination programs. Sporadic outbreaks of MD occur and can be accounted for increased virulence of MDV-1 strains, presence of other infections caused mainly by immunesuppressive agents and overall management of flock. Rapid and reliable diagnosis of MD remains an important topic in control of the disease. Several PCR methods have been successfully applied for fast, very sensitive and reliable detection of MDV-1 in biological samples. In addition, PCR protocols are available to differentiate virulent MDV-1 field isolates from vaccine virus strains of all three MDV serotypes. Individual laboratories have to rely on their own reliable validated method set-up as no general standard methodologies are available. Sensitive PCR methods for identification and quantification of MDV-1 DNA have contributed to studies on virus spread.

Acknowledgment. This work was supported by Slovak Research and Development Agency of Slovak Ministry of Education grant No. APVV-15-0720.

\section{References}

Addinger HK, Calnek BW, J. Natl. Cancer Inst. 50,1287-1298, 1973. https://doi.org/10.1093/jnci/50.5.1287

Afonso CL, Tulman ER, Lu Z, Zsak L, Rock DL, Kutish GF, J. Virol. 75, 971-978, 2001. https://doi.org/10.1128/JVI.75.2.971$\underline{978.2001}$

Angamuthu R, Baskaran S, Gopal DR, Devarajan J, Kathaperumal K, J Clin. Microbiol. 50, 961-965, 2012. https://doi. org/10.1128/JCM.05408-11

Baaten BJ, Butter C, Davison TF, Vet. Immunol. Immunopathol. 100, 165-177, 2004. https://doi.org/10.1016/j. vetimm.2004.04.009

Baigent SJ, Smith LP, Currie RJW, Nair VK, J. Gen. Virol. 86, 2989-2998,2005a.https://doi.org/10.1099/vir.0.81299-0

Baigent SJ, Petherbridge LJ, Howes K, Smith LP, Currie RJW, Nair VK, J. Virol. Methods 123, 53-64, 2005b. https:// doi.org/10.1016/i.jviromet.2004.08.019 
Baigent SJ, Smith LP, Currie JW, Nair VK, Avian Pathol. 36, 467474, 2007. https://doi.org/10.1080/03079450701639319

Baigent SJ, Nair VK, Le Galludec H, J. Virol. Methods 233, 23-36, 2016. https://doi.org/10.1016/i.jviromet.2016.03.002

Becker Y, Tabor E, Asher Y, Davidson I, Malkinson M, Witter RL, Virus Genes 7, 277-287, 1993. https://doi.org/10.1007/ BF01702588

Biggs PM, Brit. Vet. J. 117, 326-334, 1961. https://doi.org/10.1016/ $\underline{\mathrm{S} 0007-1935(17) 43555-X}$

Calnek BW, Adldinger HK, Kahn DE, Avian Dis. 14, 219-233, 1970. https://doi.org/10.2307/1588466

Calnek, B.W. (2001): Pathogenesis of Marek's disease virus infection. In Hirai K (Ed): Marek's disease. Current Topics in Microbiology and Immunology, vol. 255. Springer,Berlin, pp. 25-55. https://doi.org/10.1007/9783-642-56863-3_2

Chang KS, Ohashi K, Onuma M, J. Vet. Med. Sci. 64, 1097-1101, 2002. https://doi.org/10.1292/jvms.64.1097

Cheng YQ, Lee LF, Smith EJ, Witter RL, Avian. Dis. 28, 900-911, 1984. https://doi.org/10.2307/1590266

Chubb RC, Churchill AE, Vet. Rec. 85, 303-305, 1969. https://doi. org/10.1136/vr.85.11.303

Churchill AE, Biggs PM, Nature 215, 528-530, 1967. https://doi. org/10.1038/215528a0

Churchill AE, Payne LN, Chubb RC, Nature 22, 744-747, 1969a. https://doi.org/10.1038/221744a0

Churchill AE, Chubb RC, Baxendale W, J. Gen. Virol. 4, 557-564, 1969b. https://doi.org/10.1099/0022-1317-4-4-557

Cui Z, Qin A, Lee LF, Wu P, Kung HJ, Acta Virol. 43, 169-173, 1999.

Davidson I, Borowsky A, Perl S, Malkinson M, Avian Pathol.24,6994, 1995. https://doi.org/10.1080/03079459508419050

Davidson I, Maray T, Malkinson M, Becker Y, J. Virol. Methods 13, 231-244, 1986. https://doi.org/10.1016/01660934(86)90017-0

Davison F, Nair V, Expert Rev Vaccines 4, 77-88, 2005. https:// doi.org/10.1586/14760584.4.1.77

Fukuchi K, Tanaka A, Schierman LW, Witter RL, Nonoyama M, Proc. Natl. Acad. Sci. USA 82, 751-754, 1985. https://doi. org/10.1073/pnas.82.3.751

Gall S, Kőrösi L, Cortes AL, Delvecchio A, Prandini F, Mitsch P, Gimeno IM, Avian Pathol.47, 427-433, 2018. https://doi. org/10.1080/03079457.2018.1473555

Haider SA, Lapen RF, Kenzy SG, Poult. Sci. 49, 1654-1657, 1970. https://doi.org/10.3382/ps.0491654

Haq K, Fear T, Ibraheem A, Abdul-Careem FA, Sharif S, Avian Pathol. 41, 69-75, 2012. https://doi.org/10.1080/03079 457.2011.640304

Ikuta K, Honma H, Maotani K, Ueda S, Kato S, Hirai K, Biken J. 25, 171-175, 1982.

Isfort R, Jones D, Kost R, Witter R, Kung HJ, Proc. Natl. Acad. Sci. USA 89, 991-995, 1992. https://doi.org/10.1073/ pnas.89.3.991

Izumiya Y, Jang HK, Ono M, Mikami T (2001): A complete genomic DNA sequence of Marek's disease virus type 2, strain HPRS24. In Hirai K (ED.): Marek's Disease. Curr. Top. Microbiol. Immunol. 255. Springer-Verlag Berlin Heidelberg, pp. 191-221. https://doi.org/10.1007/978-3642-56863-3_8
King AMQ, Adams MJ, Carstens EB, Lefkowitz EJ (2012) Family - Herpesviridae. In Virus Taxonomy, Ninth Report of the International Committee on Taxonomy of Viruses, Elsevier, pp.111-122. https://doi.org/10.1016/B978-0-12384684-6.00007-0

Kingham BF, Zelnik V, Kopacek J, Majerciak V, Ney E, Schmidt CJ, J. Gen. Virol. 82, 1123-1135, 2001. https://doi. org/10.1099/0022-1317-82-5-1123

Kopáček J, Ross LJ, Zelník V, Pastorek J, Acta Virol. 37, 191-195, 1993.

Lee LF, Liu X, Witter RL, J. Immunol. 130, 1003-1006, 1983.

Majerčiak V, Valkova A, Szabova D, Geerligs H, Zelnik V, Acta Virol. 45, 101-108, 2001.

Maotani K, Kanamori A, Ikuta K, Ueda S, Kato S, Hirai K, J. Virol. 58, 657-660, 1986. https://doi.org/10.1128/JVI.58.2.657$\underline{660.1986}$

Matiasek K, Bader S, Kothlow S, Trapp S, Schwarz S, Phillip HC, Weigend S, Preisinger R, Zelnik V, Schmahl W, Kaspers B, Acta Neuropathol. 116, 339-357, 2008.

Morimura T, Ohashi K, Sugimoto C, Onuma M, J. Vet. Med. Sci. 60, 1-8, 1998. https://doi.org/10.1292/jvms.60.1

Nazerian K, J. Natl. Cancer Inst. 44, 1256-1267, 1970.

Nazerian K, Solomon JJ, Witter RL, Burmester BR, Proc. Soc. Exp. Biol. Med. 127, 177-182, 1968. https://doi. org/10.3181/00379727-127-32650

Okazaki W, Purchase HG, Burmester BR, Avian Dis. 14, 413-429, 1970. https://doi.org/10.2307/1588488

Payne LN, Frazier JA, Powell PC, Int. Rev. Exp. Path. 16, 59-154, 1976. https://doi.org/10.1017/S0020860400009347

Rispens BH, van Vloten H, Mastenbroek N, Maas HJL, Schat KA, Avian Dis. 16, 108-125, 1972a. https://doi. org/10.2307/1588905

Rispens BH, van Vloten $H$, Mastenbroek N, Maas JL, Schat KA, Avian Dis. 16, 126-138, 1972b. https://doi. org/10.2307/1588906

Ross N, Binns NM, Sanderson M, Schat KA, Virus Genes 7, 33-51, 1993. https://doi.org/10.1007/BF01702347

Schat KA, Calnek BW, J. Nat. Can. Inst.60,1075-1082,1978. https:// doi.org/10.1093/inci/60.5.1075

Schat KA, Avian Pathol. 34, 91-95, 2005. https://doi. org/10.1080/03079450500059289

Silva RF, Avian Dis. 36, 521-528, 1992. https://doi.org/10.2208/ prohe.36.521

Silva RF, Calvert JG, Lee LF, Avian Dis. 41, 528-534, 1997. https:// doi.org/10.2307/1592141

Solomon JJ, Witter RL, Nazerian K, Burmester BR, Proc. Soc. Exp. Biol. Med. 127, 173-177, 1968. https://doi. org/10.3181/00379727-127-32649

Spatz SJ, Volkening JD, Gimeno IM, Heidari M, Witter RL, Virus Genes 45, 526-536, 2012. https://doi.org/10.1007/ s11262-012-0792-Z

Tulman ER, Afonso CL, Lu Z, Zsak L, Rock DL, Kutish GF, J. Virol. 74, 7980-7988, 2000. https://doi.org/10.1128/ JVI.74.17.7980-7988.2000

Walkden-Brown SW, Islam AF, Groves PJ, Rubite A, Sharpe SM, Burgess SK, Avian Dis. 57, 544-554, 2013. https://doi. org/10.1637/10380-92112-REG.1 
Wei X, Shi X, Zhao Y, Zhang J, Wang M, Liu C, Cui H, Hu S, Quan Y, Chen H, Wang Y, J. Virol. Methods 183, 196-200, 2012. https://doi.org/10.1016/j.jviromet.2012.04.014

Witter RL, Nazerian K, Purchase HG, Burgoyne GH, Am. J. Vet. Res. 31, 525-538, 1970.

Witter RL, Gimeno IM, Reed WM, Bacon LD, Avian. Dis. 43, 704-720, 1999. https://doi.org/10.2307/1592740

Witter RL, Calnek BW, Buscaglia C, Gimeno IM, Schat KA, Avian Pathol.34,75-90, 2005. https://doi.org/10.1080/ $\underline{03079450500059255}$

Woźniakowski G, Samorek-Salamonowicz E, Kozdruń W, Avian Dis. 55, 462-467, 2011. https://doi.org/10.1637/9668012711-ResNote. 1

Woźniakowski G, Samorek-Salamonowicz E, Kozdruń W, Avian Dis. 57 (Suppl.), 539-543, 2013. https://doi. org/10.1637/10328-082012-ResNote.1
Zelnik V, Harlin O, Fehler F, Kaspers B, Göbel TW, Nair VK, Osterrieder N, J. Vet. Med. B Infect. Dis. Vet. Public Health. 51, 61-67, 2004. https://doi.org/10.1111/j.14390450.2004.00728.x

Zelnik V, Bernardi G, Wozniakowski G, Philipp H, Rebeski DE (2008): CVI988/Rispens-specific real-time method: implications for monitoring of vaccination against Marek's disease and for diagnostics of Marek's disease virus 1.8th International Marek's Disease Symposium. July 2008, Townsville, Australia.

Zeng F, Mu M, Ma L, Han Z, Shi Y, Zhang Y, Liu Ch, Yhang S, Cong F, Liu S, Mol. Cell. Probes 48, 101468, 2019. https://doi. org/10.1016/j.mcp.2019.101468 